\title{
MENGEMBANGKAN SISTEM PENYULUHAN PERTANIAN, PERIKANAN, DAN KEHUTANAN DALAM RANGKA IMPLEMENTASI UNDANG-UNDANG NOMOR 16 TAHUN 2006
}

\author{
Developing System of Agricultural Extension, Fisheries and Forestry by The Enactment of Law \\ $16 / 2006$
}

\author{
Dwi Sadono ${ }^{1)}$
}

Departemen Sains Komunikasi dan Pengembangan Masyarakat, Fakultas Ekologi Manusia, IPB

*) Email : $\underline{\text { dwisadono@yahoo.com }}$

Diterima 26 Juni 2006 /Disetujui 25 November 2010

\begin{abstract}
The enactment of Law 16/2006 on System of Agricultural Extension, Fisheries and Forestry may be marked as the new era in agricultural extension development of Indonesia. It is realized so far, that there has been no significant progress to that issue since the extension service had been administratively shifted from the central government to regional authority. Lack of local authority commitment on funding the extension services has made agricultural extension activities remained undeveloped during the years. With Law 16/2006, extension services gained sufficient legal-basis to be undertaken and thus financed by regional authority. This article is part of study to see sub-systems of extension, i.e. extension policy, agricultural extension, research and inspection, special education/official duty, and training. These sub-systems build up an integrative extension system that determines the success of agricultural extension mission at large. This writing tries to elaborate how better functional interconnection among those sub-systems could help increase the effectiveness of agricultural extension activities in the field.
\end{abstract}

Keywords: Law 16/2006, agricultural extension system, research and development, training.

\section{LATAR BELAKANG}

Kegiatan penyuluhan pertanian di Indonesia telah mempunyai sejarah yang cukup panjang, yaitu dimulai sejak awal abad 20. Dengan hasil yang cukup menggembirakan pada waktu itu, usaha-usaha ini terus dikembangkan dan kemudian dibentuk suatu sistem penyuluhan pertanian yang melembaga di Indonesia dengan dibentuknya Dinas Penyuluhan (Landbouw Voorlichting Dients atau LVD) pada tahun 1908 di bawah Departemen Pertanian (BPLPP, 1978; Iskandar, 1969).

Penyuluhan pertanian dalam perjalanan waktu telah mengalami pasang surut. Sejalan dengan penerapan otonomi daerah yang dimulai tahun 2001, maka urusan penyuluhan juga diserahkan kepada pemerintah daerah dan hal ini banyak dituding telah menyebabkan mundurnya penyuluhan pertanian (Ekstensia, 2005). Pemerintah daerah memiliki persepsi yang beragam hingga yang menganggap bahwa kelembagaan penyuluhan pertanian sebagai kelembagaan yang kurang memiliki kontribusi terhadap pengembangan daerahnya. Hal ini terbukti dari beragamnya kelembagaan penyuluhan pertanian yang dibentuk di daerah setelah diberlakukan otonomi daerah, mulai dari dinas, badan, kantor, sub dinas, seksi, UPTD, atau kelompok jabatan fungsional, bahkan 61 kabupaten/kota yang tidak jelas kelembagaan penyuluhan pertaniannya.
Menurut Slamet (2001), penyuluhan pertanian yang progresif dan efektif dapat dikembangkan oleh tenagatenaga profesional di bidang penyuluhan pertanian. Hal ini hanya dimungkinkan apabila program penyuluhan didukung oleh sistem kelembagaan penyuluhan yang terpadu antar unsur-unsurnya. Sejalan dengan pemikiran tersebut, pemerintah telah melakukan berbagai upaya diantaranya adalah dengan dicanangkannya Revitalisasi Penyuluhan Pertanian (RPP), yaitu suatu upaya mendudukkan, memerankan dan memfungsikan serta menata kembali penyuluhan pertanian agar terwujud satu kesatuan pengertian, kesatuan korps, dan kesatuan arah kebijakan (Ekstensia, 2003). Salah satu tonggak untuk pelaksanaan revitalisasi ini adalah telah disyahkannya Undang-undang Sistem Penyuluhan Pertanian, Perikanan, dan Kehutanan (SP3K) No. 16 Tahun 2006. Namun lebih dari tiga tahun setelah diundangkannya UU tersebut, baru sebagian kecil daerah yang telah membentuk kelembagaan penyuluhan sesuai dengan amanah UU penyuluhan tersebut.

\section{Penyuluhan Sebagai Suatu Sistem}

Sistem dapat didefinisikan sebagai kesatuan dari banyak unsur yang menghasilkan output tertentu. Masing-masing bagian bekerja sendiri dan bersama-sama saling mendukung dan dimaksudkan untuk mencapai tujuan bersama (Loomis, 1960). Masing-masing komponen mempunyai fungsi sendiri yang berbeda satu dengan 
lainnya. Fungsi komponen yang satu dipengaruhi oleh fungsi komponen lainnya yang berhubungan dengannya. Sebagai sistem menghasilkan output tertentu, dimana kualitas ouput yang dihasilkannya akan tergantung pada kualitas fungsi setiap komponennya. Kalau salah satu komponen tidak ada atau tidak berfungsi dengan baik maka fungsi sistem akan terganggu atau tidak berfungsi sama sekali. Karena sistem bersifat dinamis maka unsurunsurnya harus mengikuti dinamika tersebut (Slamet, 2008).

Sistem merupakan suatu rangkaian berbagai unsur yang satu sama lain berhubungan secara utuh tanpa dapat dipecah-pecahkan. Menurut Abdulsyani (1994), istilah sistem berasal dari bahasa Yunani yaitu systema yang mempunyai pengertian sebagai suatu keseluruhan yang tersusun dari sekian banyak bagian ataupun sebagai hubungan yang berlangsung di antara satuan-satuan atau komponen secara teratur. Sistem adalah himpunan dari bagian-bagian yang saling berkaitan, masing-masing bagian bekerja sendiri dan bersama-sama saling mendukung; semuanya dimaksudkan untuk mencapai tujuan bersama, dan terjadi pada lingkungan yang kompleks.

Sistem Penyuluhan Pertanian, Perikanan dan Kehutanan (selanjutnya disebut Sistem Penyuluhan) menurut Undang-Undang No 16 Tahun 2006 adalah seluruh rangkaian pengembangan kemampuan, pengetahuan, keterampilan, serta sikap pelaku utama dan pelaku usaha melalui penyuluhan. Dalam membangun sistem penyuluhan tersebut, menurut Slamet (2008) harus dilanjutkan dengan memikirkan dan menentukan segala prasarana dan sarana dalam bentuk lembaga-lembaga yang diperlukan untuk dapat menjalankan penyuluhan pembangunan dengan lancar, efektif dan efisien. Prasarana yang perlu dibangun tersebut termasuk kebijakan-kebijakan dasar yang relevan. Sarana yang diperlukan menyangkut sumberdaya-sumberdaya yang diperlukan untuk mendukung operasionalisasi kelembagaan-kelembagan yang diperlukan dalam menjalankan sistem penyuluhan. Hal ini karena keberhasilan penyuluhan tergantung bukan hanya kepada yang ada di tingkat lapangan, tetapi tergantung kepada banyak pihak.

Oleh karena itu, tulisan ini mencoba membahas mengenai sistem penyuluhan yang diperlukan agar penyuluhan pertanian sebagaimana diamanahkan dalam UU No. 16 Tahun 2006 dapat dilaksanakan dengan baik sehingga tujuan pemberdayaan petani dapat tercapai secara efektif dan efisien. Komponen sistem penyuluhan yang terutama dibahas di sini adalah: (1) institusi atau lembaga penyuluhan, (2) lembaga penelitian dan pengembangan, (3) lembaga pendidikan khusus, (4) lembaga pelatihan, dan (5) lembaga penyusun kebijakan penyuluhan.

\section{KONDISI-KONDISI SEBELUMNYA PADA SISTEM PENYULUHAN}

Kondisi-kondisi yang akan diuraikan di bawah ini tentang masing-masing sub-sistem dalam sistem penyuluhan lebih banyak tentang kondisi-kondisi pada sektor pertanian.

\section{Sub-Sistem Kelembagaan Penyuluhan}

Perjalanan seabad penyuluhan pertanian di Indonesia telah mengalami pasang surut. Dalam kesempatan ini hanya akan dibahas secara singkat perjalanan penyuluhan pertanian yang berlangsung sejak masa Pelita hingga sekarang. Masa Pelita ini ditandai dengan dimulainya periode pembangunan perekonomian negara yang lebih sistematis yang tertuang dalam Rencana Pembangunan Lima Tahun (Repelita).

Pada masa Pelita ini ditandai dengan peningkatan permintaan beras yang sangat besar yang diakibatkan oleh peningkatan kesejahteraan penduduk dan peralihan pangan pokok dari non beras ke beras. Seiring dengan kondisi tersebut, penyuluhan pertanian juga ikut berubah. Jika semula penyuluhan menekankan pada bimbingan kepada petani dalam berusahatani yang baik, berubah menjadi tekanan pada alih tehnologi, yakni mengusahakan agar petani mampu meningkatkan produktivitas dan produksinya dan menekankan pada tercapainya target produksi padi, baik target nasional, daerah maupun lokal (Tjitropranoto, 2003). Program tersebut dikenal dengan "revolusi hijau".

Untuk itu, pada sisi kelembagaan dibentuk dan dikoordinasikan kelembagaan penyuluhan dari pusat sampai tingkat lapangan. Di tingkat lapang, Balai Pendidikan Masyarakat Desa (BPMD) atau lainnya yang mempunyai tugas kewajiban sejenis pada tahun 1976 dilebur menjadi Balai Penyuluhan Pertanian (BPP) (BPLPP, 1978). Aparatur penyuluhan pertanian ditata menurut sistem Penyuluh Pertanian Lapangan (PPL) di tingkat Wilayah Unit Desa (Wilud, 600-1.000 ha ekuivalen sawah). Mereka dibina sehari-harinya oleh Penyuluh Pertanian Madya (PPM) yang berkedudukan di BPP. Penyuluh bertugas secara polivalen. Agar penyuluh dapat berperan dengan baik, maka para penyuluh secara berkala mendapatkan bahan-bahan penyuluhan melalui latihan. Model penyuluhan seperti di atas dikenal dengan Training and Visit $(\mathrm{T} \& \mathrm{~V})$ atau Latihan dan Kunjungan (LAKU).

Pendekatan penyuluhan melalui sistem kerja LAKU ini dianggap cocok pada masa itu. Sebagaimana diungkapkan oleh Axinn (1988), bahwa pendekatan LAKU lebih cocok apabila PPL masih kurang terlatih, kurangnya supervisi dan dukungan logistik. Pendekatan ini terutama ditujukan untuk mendorong petani meningkatkan produksi tanaman tertentu, yang dalam kasus Indonesia adalah beras. Demikian pula dalam hal perencanaan programnya dilakukan secara terkontrol oleh pusat (Centrally Controlled). Hasil penelitian di lapangan menunjukkan beberapa kelemahan sistem LAKU (Girsang, 1989), diantaranya: terlalu banyak menyita waktu PPL, sulitnya mengumpulkan petani yang sekelompok, dan sebagainya.

Tahun 1991 ditandai dengan mulai diserahkannya urusan penyelenggaraan penyuluhan pertanian ke daerah dengan dikeluarkannya SKB Mendagri dan Menteri Pertanian No. 65 Tahun 1991 dimana tanggung jawab penyelenggaraan penyuluhan pertanian tingkat pusat berada di tangan Mentan dibantu oleh Dirjen di lingkup Deptan dan Kepala Badan Pendidikan dan Latihan Pertanian (BPLP). Di tingkat I dan II penyelenggaraan penyuluhan dilakukan 
oleh Kepala Daerah TK I/II dan dibantu oleh Kepala Dinas Dati I/II lingkup pertanian. Bimbingan teknis penyuluhan di daerah dilakukan oleh Kakanwil untuk Dati I dan salah satu Kepala Dinas Dati II di lingkup pertanian yang ditunjuk oleh Bupati/ Walikota. Mekanisme ini merupakan perubahan yang cukup mendasar dalam pelaksanaan penyuluhan pertanian di Indonesia yang sebelumnya menganut sistem sentralisasi.

Perubahan sistem penyuluhan ini diikuti oleh perubahan peran BPP yang semula berfungsi sebagai pusat kegiatan penyuluhan, satuan administrasi pangkal PPL dan tempat demonstrasi, menjadi unit penunjang kegiatan di bidang penyuluhan pertanian. Pusat kegiatan penyuluhan dan satuan administrasi PPL kemudian ada di dinas-dinas lingkup pertanian. Asset BPP diserahkan ke pemerintah daerah, kecuali penyuluh berpendidikan sarjana pertanian. Dampak lebih adalah WKPP yang semula ditetapkan atas dasar hamparan area wilkel/ jumlah kelompok, ditetapkan atas dasar kondisi perkembangan pertanian yang bersifat dinamis dalam pengelolaan dinas lingkup pertanian yang dipilih atas dasar komoditas dominan di wilayah itu (Hubeis, 1993). Kebijakan ini menunjukkan adanya kecenderungan pola penyuluhan monovalen atau pendekatan komoditi spesifik. BPP sebagai unit penunjang juga telah dipisahkan menjadi BPP Perkebunan, BPP Tanaman Pangan, BPP Perikanan, dan BPP Peternakan.

Kondisi penyuluhan selama periode 1991-1996 banyak digambarkan sebagai "masa suram" atau "masa kelabu" bagi korps penyuluhan pertanian di Indonesia (Pusluhtan, 1995). Pengelolaan BPP sebagian besar mengalami kemunduran. Sebagai unit penunjang, maka BPP tidak lagi menyusun programma dan tidak merupakan markas (home base) penyuluh dan petani-nelayan. Disamping itu, terjadi hubungan yang kurang serasi antar penyuluh. Keadaan ini disebabkan karena semakin berkembangnya egoisme subsektoral di antara dinas-dinas lingkup pertanian.

Mulai tahun 1996 berdasarkan kepada SKB Menteri Dalam Negeri dan Menteri Pertanian No. 54 Tahun 1996 dan No. 301/Kpts/LP.120/4/96 tentang Pedoman Penyelenggaraan Penyuluhan Pertanian, dibentuk Balai Informasi dan Penyuluhan Pertanian (BIPP) yang merupakan unit kerja organik yang berada di bawah dan bertanggung jawab kepada Bupati/Walikotamadya Daerah Tingkat II. BIPP menjadi satuan administrasi pangkal dari para penyuluh. Namun ternyata bahwa proses penarikan penyuluh dari masing-masing dinas ke BIPP tidak berjalan dengan mulus karena banyak dinas merasa keberatan (Mugniesyah dan Sadono, 1998).

Belum semua kabupaten/kota di Indonesia mengukuhkan kelembagaan BIPP sebagai penyelenggara penyuluhan, telah dimulai pelaksanaan otonomi daerah pada tahun 2001. Menurut Slamet (2001), otonomi daerah ternyata membuat nasib penyuluhan pertanian lebih centang merentang lagi. Struktur kelembagaan penyuluhan di tingkat kabupaten yang bernama Balai Informasi dan Penyuluhan Pertanian (BIPP) mendadak diubah sontak di sebagian besar daerah tingkat II. Hal ini menyebabkan rumah para penyuluh pertanian menjadi tidak sama di tiap daerah, dimana ada yang tetap di BIPP, yang lain berubah menjadi KIPP, unit di bawah dinas lingkup pertanian (bidang, seksi), UPT, atau hanya berupa kelompok jabatan fungsional di dinas. Pada tahun 2005, kelembagaan penyuluhan pertanian di kabupaten/kota meliputi BIPP 23 buah, Badan 10 buah, Kantor 67 buah, Sub Dinas 86 buah, Seksi 24 buah, UPTD 25 buah, kelompok jabatan fungsional 140 buah, dan 61 kabupaten/kota tidak jelas kelembagaan penyuluhan pertaniannya, dan hanya 3.557 BPP dari 5.187 kecamatan (Ekstensia, 2005).

\section{Sub-Sistem Kelembagaan Penelitian dan Pengkajian}

Sistem penyuluhan pembangunan (modern) memerlukan dukungan lembaga pengkajian dan penelitian. Hal ini didasarkan pada pemikiran bahwa sistem penyuluhan pembangunan harus berbasis kepada ilmu pengetahuan dan penelitian. Oleh karena itu, lembaga-lembaga pengkajian dan penelitian seharusnya bekerja untuk mendukung penyuluhan, merupakan satu sistem dengan lembaga penyuluhan atau ada kerjasama yang harmonis (Slamet, 2008).

Melalui kegiatan penelitian yang teratur dan intensif telah banyak ditemukan teknologi pertanian baik teknologi produksi maupun pengolahan. Namun demikian, sebagian dari teknologi tersebut ternyata tidak diadopsi oleh petani yang diduga disebabkan karena: (1) keterbatasan teknologi yang belum mampu menjawab tantangan bersifat lokal spesifik, (2) teknologi yang diintroduksikan belum mampu menyentuh kebutuhan dasar petani, (3) rekomendasi teknologi seringkali berlaku umum sedangkan kondisi sosial ekonomi dan bio-fisik antara daerah sangat beragam, dan (4) dalam proses adopsi teknologi, unsur partisipatori belum mendapat perhatian yang proporsional (Pasandaran dan Adnyana, 1995).

Dalam proses adopsi teknologi diperlukan adanya keterkaitan yang erat antara berbagai unsur seperti sumber teknologi (lembaga penelitian/pengkajian), penyuluhan, petani, pengaturan dan pelayanan. Masing-masing unsur mempunyai peranan sendiri tetapi antar unsur saling terkait. Mekanisme penyampaiaan hasil penelitian pada masa Orde Baru pada dasarnya mengikuti pendekatan top down (Pasandaran dan Adnyana, 1995). Hasil penelitian disampaikan kepada Direktorat Teknis yang kemudian melakukan pengujian-pengujian lebih lanjut. Hasil pengujian itu dirakit menjadi petunjuk teknis yang lebih sederhana. Juknis disam-paikan kepada Kanwil Pertanian yang kemudian diserahkan ke Dinas Teknis dan disebarluaskan kepada penyuluh. Melalui pertemuan-pertemuan teknis, juknis tersebut disampaikan kepada penyuluh pertanian lapangan (PPL) sebagai materi penyuluhan kepada petani.

Mekanisme dengan jalur yang cukup panjang tersebut sering menyebabkan informasi tentang teknologi baru terlambat sampai kepada petani, atau modifikasi yang dilakukan menyebabkan teknologi itu dapat berbeda dengan yang dianjurkan oleh lembaga penelitian. Berdasarkan kelemahan tersebut dan makin besarnya tantangan dalam pembangunan pertanian, maka dicoba alternatif lain yang lebih dinamis untuk mempercepat proses produksi, antara lain adalah dengan membentuk Balai/Loka Pengkajian Teknologi Pertanian

324 | Sadono, Dwi. Mengembangkan Sistem Penyuluhan Pertanian, Perikanan, dan Kehutanan dalam Rangka Implementasi Undang-Undang Nomor 16 Tahun 2006 
(BPTP/LPTP) di tiap propinsi mulai tahun 1997. Di BPTP/LPTP bergabung peneliti dan penyuluh. Tugas BPTP adalah melaksanakan penelitian komoditas, pengujian dan perakitan teknologi tepat guna spesifik lokasi. BPTP didirikan di setiap propinsi dengan cara memanfaatkan aset yang ada di BIP (Balai Informasi Pertanian) sebagai lembaga pengkajian teknologi pertanian, berlaku sejak April 1995. Dengan demikian BIP yang telah mengabdi 15 tahun dinyatakan berakhir.

Pembentukan BPTP/LPTP ini untuk mewujudkan keterkaitan peneliti dan penyuluh dan diharapkan teknologi yang dihasilkan menjadi lebih spesifik lokasi dan sesuai dengan kebutuhan petani. Namun demikian, hal ini juga tidak dapat berjalan dengan mulus karena hasil-hasil penelitian BPTP/LPTP belum dapat menjawab kebutuhan petani. Untuk menghasilkan suatu teknologi dibutuhkan dana, tenaga, dan waktu yang cukup banyak. Proses perakitan teknologi yang spesifik lokasi menjadi sangat mahal. Oleh karena itu, teknologi yang tersedia untuk masing-masing agroekosistem masih relatif terbatas dan belum mampu menjangkau setiap tipe agroekosistem yang ada sehingga masih banyak teknologi yang direkomendasikan masih bersifat umum. Masalah lain yang timbul adalah tidak adanya sinergi antara peneliti dan penyuluhnya dimana peneliti dapat menyuluhkan sendiri hasil pengkajiannya atau penyuluh melakukan pengkajian sendiri.

\section{Sub-Sistem Kelembagaan Pendidikan Khusus (Kedinasan)}

Lembaga pendidikan khusus/kedinasan diselenggarakan untuk mendidik tenaga penyuluh seuai dengan keperluan, baik untuk meningkatkan kompetensi khusus maupun untuk keperluan penjenjangan. Lembaga pendidikan khusus/ kedinasan ini seperti Sekolah Tinggi Penyuluhan Pertanian (STPP) yang menyelenggarakan pendidikan Diploma 4. Menurut Slamet (2008), lembaga pendidikan khusus perlu dirancang dan direncanakan dengan matang, bukan hanya program-programnya tetapi juga prasarana dan segala sarananya. Program dan kurikulumnya perlu disesuaikan dengan kebutuhan kompetensi tenaga kerja yang dibutuhkan. Kondisi belakangan ini, lembaga khusus ini tidak mensuplay kebutuhan instansi yang memilikinya, tetapi mensuplay kebutuhan lainnya.

\section{Sub-Sistem Kelembagaan Pelatihan}

Lembaga pelatihan bertugas menyusun sistem pelatihan bagi penyuluh, melatih para penyuluh untuk meningkatkan kompetensi tertentu dengan tujuan untuk memperkuat pelaksanaan tugas lapangan sehari-hari. Sistem pelatihan menyangkut: siapa yang dilatih, siapa yang melatih, dilatih apa, kapan dilatihnya, apa tujuan masing-masing pelatihan dan sebagainya. Latihan-latihan ini harus bersistem dan berjadwal sehingga diketahui oleh para penyuluh. Dalam sistem pelatihan itu juga harus melekat insentif yang berkaitan dengan jabatan sebagai penyuluh, sehingga menarik untuk diikuti dan berguna untuk karirnya. Insentif dapat berupa angka kredit ataupun persyaratan untuk mengikuti aktivitas-aktivitas lainnya.

Pendekatan penyuluhan yang dilaksanakan pada masa Bimas sampai Insus adalah melalui sistem kerja Latihan dan Kunjungan (LAKU). Pada sistem ini setiap WKPP yang luasnya 600-1000 hektar ekuivalen sawah dibagi lagi dalam 16 wilayah kelompok (wilkel) dimana PPL yang bersangkutan secara teratur dan berkelanjutan melakukan anjangkarya di hamparan usahatani.

Kemampuan PPL dalam membina kelompok tani ditetapkan berdasarkan rasio antara Kepala Keluarga tani (KK Tani) dengan PPL. Untuk wilayah Jawa dan Bali misalnya ditetapkan $1: 1.600$. Penyuluh Pertanian Lapangan (PPL) pada periode ini bersifat polivalen, yang artinya penyuluh dituntut harus mampu memberikan materi penyuluhan yang mencakup semua komoditas pertanian, antara lain tanaman pangan, perkebunan, perikanan dan peternakan. Dalam sistem LAKU, dua kali dalam sebulan PPL mengikuti latihan di BPP yang dibimbing oleh PPM/PPS. Empat hari dalam seminggu mengadakan kunjungan ke 8 kelompok tani untuk mengadakan diskusi, pemecahan masalah petani ataupun merekomendasikan teknologi baru. Satu hari lainnya dalam seminggu digunakan untuk membuat laporan.

Pada masa transisi (1991-1996), sistem kerja atau pendekatan penyuluhan LAKU (latihan dan kunjungan) semakin kurang efektif karena banyak didasarkan kepada perencanaan yang "top down" dan kurang menunjang pengembangan usahatani yang berwawasan agribisnis. Latihan dalam pola LAKU juga semakin berkurang karena informasi baru yang dilatihkan kepada petani semakin berkurang.

Dari hasil kunjungan lapangan ke Balai Besar Pelatihan Pertanian (BBPP) Lembang, Pusat Pendidikan dan Pelatihan Manajemen Sumberdaya Manusia Pertanian (P3MSDMP) Ciawi dan Badan Pelaksana Penyuluhan Pertanian, Perikanan dan Kehutanan (BP4K) Kabupaten Sukabumi pada tahun 2008 menunjukkan bahwa pelatihan untuk penyuluh pertanian semakin berkurang. Hal ini disebabkan karena keterbatasan anggaran dan kurangnya koordinasi antara pusat pelatihan dengan lembaga pelaksana penyuluhan.

\section{Sub-Sistem Kelembagaan Pembuat Kebijakan}

Sub sistem ini bertugas menyusun kebijakan/rencana strategis yang menjamin adanya dan berlangsungnya penyuluhan secara efektif dan berkelanjutan. Sebagai sub sistem kebijakan adalah pemerintah mulai dari pusat, propinsi, hingga kabupaten/kota beserta dewan perwakilan pada setiap level tersebut yang berfungsi sebagai badan legislasi dan pengaturan pembiayaan. Hal ini karena dalam UU No. 16/2006 disebutkan bahwa pembiayaan kegiatan penyuluhan dibebankan kepada anggaran APBN dan APBD.

Untuk melaksanakan sistem penyuluhan sebagaimana ditetapkan dalam UU No. 16/2006, dibutuhkan peraturanperaturan yang dikeluarkan oleh Presiden, Gubernur, hingga Bupati/Walikota dan DPRD di berbagai level. Dalam hal ini, Sarma (2008) menyatakan bahwa untuk melaksanakan fungsi pengorganisasian agar UU No. 16/2006 dapat terlaksana dari tingkat pusat hingga kecamatan diperlukan dua buah Peraturan Presiden, satu Peraturan Menteri), dua Peraturan Gubernur, dan tiga Peraturan Bupati/Walikota. Selain itu, untuk mengimplementasikan UU No. 16/2006 secara 
keseluruhan, dibutuhkan lagi dua Peraturan Pemerintah, dua Peraturan Menteri, serta empat peraturan yang dikeluarkan oleh Menteri, Gubernur, atau Bupati/Walikota. Dengan demikian, diperlukan 16 peraturan yang diperlukan untuk mengimplementasikan UU No. 16/2006. Tentunya hal ini tidak akan menjadi masalah, jika semangat keberpihakan akan dilaksanakannya UU tersebut kuat sehingga peraturanperaturan tersebut dikerjakan dengan sungguh-sungguh. Namun masalahnya, sampai sekarang belum satupun peraturan yang menyangkut UU tersebut dikeluarkan. Hal ini tentunya menjadikan kekahawatiran bagi para stakeholder.

Selain komponen-komponen sistem penyuluhan di atas, maka hal yang turut mendukung efektifitas penyuluhan (terutama ada pada subsistem kelembagaan penyuluhan) adalah masalah: sumberdaya manusia penyuluh, pendanaan penyuluhan, dan penjenjangan karir penyuluh. Ketiga hal ini juga terkait dengan lembaga yang menyusun kebijakan/rencana strategis yang menjamin adanya dan berlangsungnya penyuluhan secara efektif dan berkelanjutan

\section{Sumberdaya Manusia Penyuluh}

Sistem penyuluhan harus didukung oleh sumberdaya manusia (SDM) penyuluh yang sesuai. Hal-hal yang menjadi pertimbangan menurut Slamet (2008) diantaranya adalah: masalah sosial yang dihadapi, kelompok sasaran, strategi pemecahan masalah, strategi pendekatan masalah, tingkat keakuratan pemecahan masalah, pendanaan yang tersedia, perkembangan ilmu dan teknologi, wilayah yang akan menjadi wilayah kerja, dan keberlanjutan kebijakan.

Jumlah tenaga penyuluh dari tahun ke tahun mengalami peningkatan. Sebagai gambaran, pada tahun 1969 jumlah PPL sebanyak 672 orang dan belum ada tenaga PPS. Tahun 1977 jumlah PPL sebanyak 11.749 orang dan PPS sebanyak 1.206 orang (BPLPP, 1978). Sementara pada tahun 1991, penyuluh di Indonesia berjumlah 29.530 orang (Hubeis, 1993). Mereka terdiri dari 1.413 penyuluh berkualifikasi sarjana $(4,78 \%)$ dan 27.117 non sarjana (95,22\%). Menurut FAO (Hubeis, 1993) angka presentase penyuluh spesialis yang diharapkan menjembatani hasilhasil pertanian dalam membina penyuluh lapangan relatif sangat sedikit dibanding dengan rata-rata persentase untuk negara berkembang yang berkisar antara 8\%-20\%.

Data pada tahun 1999 menyebutkan bahwa jumlah penyuluh pertanian sebanyak 37.636 orang. Pada tahun 2001 yang merupakan tahun awal pemberlakuan otonomi daerah, jumlah penyuluh berkurang menjadi 33.659 orang. Pada tahun 2005 menyusut lagi menjadi 25.708 orang ditambah 1.634 penyuluh honorer (Ekstensia, 2005).

Dalam kaitannya dengan kemampuan penyuluh, Kepala BPSDMP menyatakan bahwa pada waktu lalu pengembangan kompetensi penyuluh pertanian masih bias kepada sub sektor tanaman pangan, khususnya padi. Kondisi ini yang menyebabkan terbatasnya pelayanan penyuluh pertanian kepada petani yang mengusahakan komoditas di luar tanaman pangan. Berkurangnya penyuluh pertanian akibat banyaknya penyuluh yang pensiun ataupun yang beralih tugas ke administrasi atau struktural juga merupakan masalah tersendiri. Akibatnya, banyak desa maupun kecamatan yang tidak memiliki lagi tenaga penyuluh (Ekstensia, 2005).

\section{Pendanaan Penyuluhan}

Sebelum masa otonomi daerah, pendanaan kegiatan penyuluhan pertanian dianggarkan oleh pemerintah pusat melalui Departemen Pertanian. Tahun 1991 dimulai era penyerahan sebagian urusan penyuluhan pertanian ke daerah. Salah satu perubahan besar dalam penyuluhan pertanian dengan dikeluarkannya SKB tahun 1991 adalah adanya penyerahan urusan penyuluhan tersebut kepada Pemerintah Daerah Tingkat II baik yang menyangkut personil penyuluh pertanian, material (sarana penyuluhan) maupun tatalaksana penyuluhan.

Dalam merealisasikan pelaksanaan desentralisasi urusan penyuluhan pertanian ini bahwa tidak semua Daerah Tingkat II mempunyai kemampuan yang sama, antara lain dalam aspek penganggaran biaya penyelenggaraan penyuluhan pertanian (Ekstensia, 1996). Oleh karenanya, untuk pelaksanaan penyuluhan pertanian di daerah masih diberikan SBBO-PP (Subsidi Bantuan Biaya Operasional Penyuluhan Pertanian) dari pemerintah pusat yang diusahakan melalui Departemen Dalam Negeri. Namun demikian, dana tersebut di beberapa daerah mengalami ketidaklancaran maupun ketidak-utuhan dalam penyaluran dana anggaran penyuluhan sampai ke tangan penyuluh (Ekstensia, 1996). Dari gambaran tersebut, tampak jelas bahwa masalah menghidupkan kembali dinamika penyuluhan pertanian di daerah dalam pelaksanaan desentralisasi penyuluhan pertanian ini tidak hanya terbatas pada ada atau tidaknya dana (anggaran) semata-mata, tetapi sekaligus menyangkut mekanisme dan manajemennya.

Pada tahun 1999 dikeluarkan UU No. 22 tahun 1999 tentang Pemerintah Daerah dan UU No. 25 Tahun 1999 tentang Perimbangan Keuangan antara Pemerintah Pusat dan Daerah. Pemberlakuan UU tersebut sebenarnya telah memberikan peluang yang cukup besar bagi kabupaten/kota untuk memunculkan kelembagaan yang cocok dengan kondisi daerahnya (Ekstensia, 2005). Namun sangat disayangkan bahwa masih banyak daerah yang memiliki persepsi beragam hingga yang menganggap kelembagaan penyuluhan pertanian sebagai kelembagaan yang kurang memiliki kontribusi terhadap pengembangan daerahnya. Hal ini terbukti dengan beragamnya kelembagaan penyuluhan pertanian yang ada seperti telah disebutkan di atas.

Setelah tiga tahun dikeluarkannya UU No. 16 Tahun 2006 tentang Sistem Penyuluhan Pertanian, Perikanan, dan Kehutanan, kondisi di atas juga masih relatif sama. Sampai November 2009, baru terdapat 181 kabupaten/kota (< 45\%), yang sudah mempunyai kelembagaan penyuluhan yang baru (BP4K). Kelembagaan koordinasi penyuluhan di propinsi (BKP3K) sudah dibentuk di 21 provinsi*) ${ }^{1}$.

\footnotetext{
${ }^{1}$ Pidato Menteri Kehutanan pada Pembukaan Rapat Koordinasi dan Konsultasi Penyuluhan Kehutanan, tanggal 16 November 2009
} 
Pembiayaan penyuluhan masih mengandalkan sumber utama dari pemerintah pusat, seperti dari Dana Alokasi Khusus (DAK), Biaya Operasional Penyuluhan (BOP), dan lainnya. Dana yang bersumber dari APBD jika sudah dikeluarkan Perda-nya, umumnya masih dalam jumlah yang sedikit.

\section{Pengembangan Karir Penyuluh}

Dengan diterbitkannya Surat Keputusan Menteri Negara Pendayagunaan Aparatur Negara (PAN) No. 73/Menpan/1985, penyuluh diberi status jabatan fungsional. Pemberian status ini dimaksudkan untuk memberi peluang tenaga penyuluh mencapai pangkat tertinggi sampai IV/c dan diharapkan akan memacu semangat kerja mereka. Jabatan fungsional penyuluh dan pangkatnya dimulai dari Asisten Penyuluh Pertanian Muda (II/a) sampai Penyuluh Pertanian Utama Muda (IV/c). Setiap jabatan fungsional diberikan tunjangan fungsional sehingga dapat meningkatkan pendapatan penyuluh.

Berdasarkan Keputusan Menteri Negara PAN Tahun 1999, penyuluh pertanian digolongkan menjadi dua, yaitu : 1) Penyuluh Pertanian Trampil, dan 2) Penyuluh Pertanian Ahli. Penyuluh Pertanian Trampil adalah jabatan fungsional penyuluh keterampilan yang dalam pelaksanaan pekerjaannya mempergunakan prosedur dan teknik kerja tertentu. Penyuluh Pertanian Ahli adalah jabatan fungsional penyuluh pertanian keahlian yang dalam pelaksanaan pekerjaannya didasarkan atas disiplin ilmu pengetahuan, metodologi dan teknik analisis tertentu. Penggolongan jabatan penyuluh pertanian trampil adalah sebagai berikut: Penyuluh Pertanian Pelaksana (II/b-II/d), Penyuluh Pertanian Pelaksana Lanjutan (III/a-III/b), dan Penyuluh Penyelia (III/c-III/d). Penyuluh Pertanian Ahli digolongkan menjadi: Penyuluh Pertanian Pratama (III/a-III/b), Penyuluh Pertanian Muda (III/c-III/d), Penyuluh Pertanian Madya (IV/a-IV/c) dan Penyuluh Pertanian Utama (IV/d-IV/e). Penyuluh pertanian ahli memperoleh kesempatan mencapai pangkat maksimum dalam karir pegawai negeri.

Penyuluh pertanian ahli pada golongan yang sama mendapatkan tunjangan fungsional yang lebih tinggi dibandingkan dengan mereka yang menjadi penyuluh pertanian trampil. Hal ini memicu penyuluh pertanian trampil setelah memperoleh gelar sarjana/diploma 4 akan minta dialihkan statusnya menjadi penyuluh pertanian ahli. Pada penyuluh pertanian yang bekerja di lapangan, hal ini menyebabkan penyuluh tidak dapat melaksanakan tugas sesuai dengan tupoksi jabatan fungsionalnya, tetapi lebih banyak melaksanakan tugas sesuai dengan tupoksi jabatan fungsional yang lebih rendah atau tetap pada tupoksi penyuluh trampil (Pramitha, 2007).

\section{PENGEMBANGAN SISTEM PENYULUHAN}

\section{Kelembagaan Penyuluhan}

Kelembagaan penyuluhan pertanian, perikanan, dan kehutanan yang disusun didasarkan pada UU No. 16 Tahun 2006 dibentuk pada tingkat pusat sampai tingkat lapangan. Pada tingkat pusat berbentuk badan yang menangani penyuluhan, pada tingkat propinsi berbentuk Badan Koordinasi Penyuluhan, dan pada tingkat kabupaten/kota berbentuk Badan Pelaksana Penyuluhan. Pada tingkat kecamatan berbentuk Balai Penyuluhan dan pada tingkat desa/kelurahan dibentuk Pos Penyuluhan Desa/Kelurahan.

Badan Penyuluhan pada tingkat pusat bertanggung jawab kepada Menteri. Badan Penyuluhan mempunyai tugas:

1. Menyusun kebijakan nasional, programa penyuluhan nasional, standarisasi dan akreditasi tenaga penyuluh, sarana dan prasarana, serta pembiayaan penyuluhan.

2. Menyelenggarakan pengembangan penyuluhan, pangkalan data, pelayanan, dan jaringan informasi penyuluhan.

3. Melaksanakan penyuluhan, koordinasi penyeliaan, pemantauan, dan evaluasi, serta alokasi dan distribusi sumberdaya penyuluhan.

4. Melaksanakan kerja sama penyuluhan nasional, regional, dan internasional.

5. Melaksanakan peningkatan kapasitas penyuluh PNS, swadaya, dan swasta.

Badan Penyuluhan ini membawahi pusat-pusat (setingkat eselon II) yang mempunyai fungsi sebagai pusat pendidikan khusus/kedinasan, pusat-pusat pelatihan.

Badan Koordinasi Penyuluhan Pertanian, Perikanan, dan Kehutanan (BKP3K) di tingkat propinsi diketuai oleh Gubernur dan dibantu oleh sekretariat yang dipimpin oleh pejabat setingkat eselon IIa. Badan ini mempunyai tugas:

1. Melakukan koordinasi, integrasi, sinkronisasi lintas sektor, optimalisasi partisipasi, advokasi masyarakat dengan melibatkan unsur pakar, dunia usaha, institusi terkait, perguruan tinggi, dan sasaran penyuluhan.

2. Menyusun kebijakan dan programa penyuluhan propinsi yang sejalan dengan kebijakan dan programa nasional serta spesifik lokalita.

3. Memfasilitasi pengembangan kelembagaan dan forum masyarakat bagi pelaku utama dan pelaku usaha untuk mengembangkan usahanya dan memberikan umpan balik kepada pemerintah daerah.

4. Melaksanakan peningkatan kapasitas penyuluh PNS, swadaya, dan swasta.

Di tingkat kabupaten/kota dibentuk Badan Pelaksana Penyuluhan Pertanian, Perikanan, dan Kehutanan (BP4K). Badan pelaksana penyuluhan ini dipimpin oleh pejabat setingkat eselon II dan bertanggung jawab kepada bupati/ walikota. Badan ini mempunyai tugas sebagai berikut:

1. Menyusun kebijakan dan programa penyuluhan kabupaten/kota yang sejalan dengan kebijakan dan programa penyuluhan nasional dan propinsi.

2. Melaksanakan penyuluhan dan mengembangkan mekanisme, tata kerja, dan metode penyuluhan.

3. Melaksanakan pengumpulan, pengolahan, pengemasan, dan penyebaran materi penyuluhan bagi pelaku utama dan pelaku usaha. 
4. Melaksanakan pembinaan pengembangan kerja sama, kemitraan, pengelolaan kelembagaan, ketenagaan, sarana dan prasarana, serta pembiayaan penyuluhan.

5. Menumbuhkembangkan dan memfasilitasi kelembagaan dan forum kegiatan bagi pelaku utama dan pelaku usaha.

6. Melaksanakan peningkatan kapasitas penyuluh PNS, swadaya, dan swasta melalui proses pembelajaran secara berkelanjutan.

Pada tingkat kecamatan dibentuk Balai Penyuluhan Pertanian, Perikanan, dan Kehutanan (BP3K). Balai ini berfungsi sebagai tempat pertemuan para penyuluh, pelaku utama dan pelaku usaha. BP3K mempunyai tugas sebagai berikut:

1. Menyusun programa penyuluhan pada tingkat kecamatan sejalan dengan programa penyuluhan kabupaten/kota dan yang spesifik lokasi.

2. Melaksanakan penyuluhan berdasarkan programa penyuluhan.

3. Menyediakan dan menyebarkan informasi teknologi, sarana produksi, pembiayaan, dan pasar.

4. Memfasilitasi pengembangan kelembagaan dan kemitraan pelaku utama dan pelaku usaha.

5. Memfasilitasi peningkatan kapasitas penyuluh PNS, penyuluh swadaya, dan penyuluh swasta melalui proses pembelajaran secara berkelanjutan.

6. Melaksanakan proses pembelajaran melalui percontohan dan pengembangan model usahatani bagi pelaku utama dan pelaku usaha.

BP3K di tingkat kecamatan ini perlu dimanfaatkan sebagai tempat peningkatan pendidikan masyarakat desa seperti yang dicita-citakan dalam pembentukan Balai Pendidikan Masyarakat Desa (BPMD) pada tahun 1948 (Soewardjo, 1953). Balai ini melayani kepentingan seluruh masyarakat desa (petani, pedagang, tukang, dan sebagainya) dan bersifat netral dari kepentingan politis (Tim Faperta IPB, 1992). Balai ini merupakan suatu tempat dengan bangunan untuk pertemuan dan lahan (1-2 ha) untuk melakukan percontohan melalui demonstrasi usahatani dan industri kecil, dan sebagainya. Dengan percontohan ini maka masyarakat desa akan mendatangi BP3K untuk melihat percontohan tersebut.

Pada tingkat desa/kelurahan dibentuk Pos penyuluhan desa/kelurahan, yang merupakan unit kerja nonstruktural yang dibentuk dan dikelola secara partisipatif oleh pelaku utama. Pos penyuluhan desa/kelurahan berfungsi sebagai tempat pertemuan para penyuluh, pelaku utama dan pelaku usaha, untuk:

1. Menyusun programa penyuluhan.

2. Melaksanakan programa desa/kelurahan

penyuluhan

3. Menginventarisasi permasalahan dan upaya pemecahannya.
4. Melaksanakan proses pembelajaran melalui percontohan dan pengembangan model usahatani bagi pelaku utama dan pelaku usaha.

5. Menumbuh kembangkan kepemimpinan, kewirausahaan, serta kelembagaan pelaku utama dan pelaku usaha.

6. Melaksanakan kegiatan rembug, pertemuan teknis, temu lapang, serta metode penyuluhan lain bagi pelaku utama dan pelaku usaha.

7. Memfasilitasi layanan informasi, konsultasi, pendidikan, serta pelatihan bagi pelaku utama dan pelaku usaha.

8. Memfasilitasi forum penyuluhan perdesaan.

\section{Lembaga Penelitian dan Pengkajian}

Sistem penyuluhan pembangunan (modern) memerlukan dukungan lembaga pengkajian dan penelitian. Hal ini didasarkan pada pemikiran bahwa sistem penyuluhan pembangunan harus berbasis kepada ilmu pengetahuan dan penelitian. Oleh karena itu, lembaga-lembaga pengkajian dan penelitian seharusnya bekerja untuk mendukung penyuluhan, merupakan satu sistem dengan lembaga penyuluhan atau ada kerjasama yang harmonis.

Lembaga penelitian dan pengkajian pertanian yang sudah ada yaitu Balai/Loka Pengkajian Teknologi Pertanian (BPTP/LPTP) agar difungsikan lebih lanjut sebagaimana tugas yang telah dirumuskan pada awal pembentukannya. BPTP/LPTP mempunyai tugas melaksanakan kegiatan penelitian komoditas, pengujian dan perakitan teknologi tepat guna (TTG) dan spesifik lokasi (Pasandaran dan Adnyana, 1995). Hal ini mengingat beragamnya kondisi bio-fisik dan sosial ekonomi antar daerah maupun antar agroekosistem.

Teknologi tepat guna (TTG) dalam hal ini mengandung pengertian bahwa lembaga pengkajian ini diharapkan mampu menghasilkan teknologi pertanian yang bersifat dinamis, sesuai dengan kebutuhan dan kemampuan masyarakat, tidak merusak lingkungan dan dapat dimanfaatkan oleh petani dalam meningkatkan nilai tambah komoditas pertanian (dalam arti luas). Spesifik lokasi adalah bahwa teknologi yang dihasilkan sesuai dengan agroekosistem setempat. Suatu agroekosisitem adalah pencerminan sifat fisik suatu wilayah seperti tipe tanah, topografi, ketersediaan air dan iklim. Pengetahuan tentang agroekosistem di suatu wilayah akan sangat membantu BPTP/LPTP dalam perakitan dan pengkajian teknologi pertanian.

Dalam melaksanakan tugas tersebut di atas, BPTP/LPTP menyelenggarakan fungsi sebagai berikut:

1. Penelitian komoditas pertanian spesifik lokasi.

2. Pengujian dan perakitan teknologi tepat guna spesifik lokasi.

3. Penyampaian umpan balik untuk penyempurnaan program penelitian pertanian.

4. Penyampaian paket teknologi hasil pengujian dan perakitan sebagai bahan materi penyuluhan bagi lembaga penyuluhan.

328 Sadono, Dwi. Mengembangkan Sistem Penyuluhan Pertanian, Perikanan, dan Kehutanan dalam Rangka Implementasi Undang-Undang Nomor 16 Tahun 2006 
5. Pelayanan teknis kegiatan pengkajian teknologi pertanian.

BPTP/LPTP merupakan salah satu sumber informasi teknologi yang dihasilkan dari kerjasama yang erat antara peneliti dan penyuluh ahli yang ada di BPTP/LPTP. Untuk mengetahui kebutuhan teknologi sesuai dengan kondisi setempat, konsultasi dua arah antara BPTP/LPTP dengan dinas-dinas terkait dan lembaga penyuluhan di tingkat propinsi maupun kabupaten/kota harus terjalin secara efisien untuk menyesuaikan antara kebutuhan dengan perakitannya di BPTP/LPTP. Teknologi yang telah matang dan sesuai dengan permintaan kemudian disusun dalam bentuk materi penyuluhan yang disampaikan kepada lembaga penyuluhan di tingkat propinsi maupun kabupaten/kota, untuk kemudian disampaikan kepada petani.

Agar terjadi kerjasama yang harmonis antara peneliti dan penyuluh ahli di BPTP/LPTP, Havelock (Asngari, 2008) memberi resep untuk membina kebersamaan diantaranya adalah sistem insentif yang seimbang antara peneliti dan penyuluh. Hal ini untuk menghindari perasaan superior dan inferior diantara peneliti dan penyuluh ahli di BPTP/LPTP. Selama ini para peneliti dan penyuluh mendapat tunjangan fungsional yang berbeda, dimana peneliti mendapat tunjangan fungsional yang lebih besar dari penyuluh. Selain itu, agar kegiatan pengkajian/penelitian yang dilakukan di tingkat BPTP/LPTP adalah yang terkait dengan upaya pemecahan masalah di tingkat petani, maka sistem insentif angka kredit untuk kenaikan jabatan fungsional/pangkat peneliti dan penyuluh perlu dilakukan perbaikan. Kegiatan penelitian/pengkajian yang berguna untuk memecahkan masalah petani perlu mendapat angka kredit yang lebih baik dibandingkan dengan angka kredit penelitian/pengkajian yang lebih berorientasi kepada publikasi di jurnal ilmiah.

\section{Lembaga Pendidikan Khusus (Kedinasan)}

Lembaga pendidikan khusus/kedinasan diselenggarakan untuk mendidik tenaga penyuluh sesuai dengan keperluan, baik untuk meningkatkan kompetensinya khusus maupun untuk keperluan penjenjangan. Lembaga pendidikan khusus/kedinasan ini seperti Sekolah Tinggi Penyuluhan Pertanian (STPP) yang menyelenggarakan pendidikan Diploma 4. Menurut Slamet (2008), lembaga pendidikan khusus perlu dirancang dan direncanakan dengan matang, bukan hanya program-programnya tetapi juga prasarana dan segala sarananya. Program dan kurikulumnya perlu disesuaikan dengan kebutuhan kompetensi tenaga kerja yang dibutuhkan.

Lembaga pendidikan khusus/kedinasan diperuntukkan untuk memenuhi kebutuhan tenaga yang sesuai dengan kualifikasi yang diperlukan atau dalam rangka peningkatan jenjang karir fungsional penyuluh. Sebagai contoh, Sekolah Tinggi Penyuluhan Pertanian (STPP) diperuntukkan bagi penyuluh yang sudah berlatar belakang pendidikan D3 penyuluhan/pertanian. Untuk mendapatkan kualifikasi lulusan yang memadai maka mutu dan jumlah tenaga pengajarnya perlu mendapatkan perhatian utama. Pemenuhan kebutuhan prasarana dan sarana fisik dapat dilakukan secara bertahap, namun tenaga pengajarnya harus dilengkapi dahulu kualitas dan jumlahnya. Disamping itu, kurikulum yang disusun perlu disesuaikan dengan kebutuhan kompetensi tenaga kerja yang dibutuhkan.

Untuk dapat mengikuti pendidikan khusus/kedinasan perlu diprioritaskan untuk peserta-peserta terpilih yang berprestasi sehingga pendidikan itu bergengsi di mata para penyuluh. Pendidikan khusus/kedinasan yang bersifat lanjutan (D4) perlu dikaitkan dengan kegiatan penjenjangan karir penyuluh. Syarat-syarat untuk ikut pendidikan lanjutan khusus/kedinasan perlu ditentukan dan diumumkan sehingga mendorong penyuluh untuk berprestasi.

Penataan program dan peningkatan kemampuan personil lembaga pendidikan khusus/kedinasan perlu dibarengi dengan aspek pembiayaan yang memadai. Hal ini karena tanpa adanya biaya yang memadai, sasaran dan target yang dicanangkan akan sulit untuk dicapai.

\section{Lembaga Pelatihan}

Lembaga pelatihan bertugas melatih para penyuluh untuk meningkatkan kompetensi tertentu dengan tujuan untuk memperkuat pelaksanaan tugas lapangan sehari-hari. Yang disebut lembaga pelatihan menurut Slamet (2008) tidak harus berbentuk gedung atau kampus, tetapi yang penting harus ada sistem pelatihan bagi tenaga penyuluh yang ada. Sistem pelatihan menyangkut: siapa yang dilatih, siapa yang melatih, dilatih apa, kapan dilatihnya, apa tujuan masing-masing pelatihan dan sebagainya. Latihan-latihan ini harus bersistem dan berjadwal sehingga diketahui oleh para penyuluh. Dalam sistem pelatihan itu juga harus melekat insentif yang berkaitan dengan jabatan sebagai penyuluh, sehingga menarik untuk diikuti dan berguna untuk karirnya. Insentif dapat berupa angka kredit ataupun persyaratan untuk mengikuti aktivitas-aktivitas lainnya.

Lembaga-lembaga pelatihan yang sudah dibentuk di bawah departemen perlu dioptimalkan untuk memenuhi kebutuhan pelatihan bagi tenaga penyuluh. Penyuluh pertanian perlu mendapatkan pelatihan secara teratur dan terprogram sehingga kemampuannya selalu mengalami peningkatan dari waktu ke waktu sesuai dengan kemampuan yang dituntut untuk mampu melaksanakan penyuluhan yang baik dan sesuai dengan kebutuhan petani.

Agar dapat memenuhi kebutuhan penyuluh, maka program pelatihan yang dilaksanakan oleh lembaga pelatihan perlu disusun berdasarkan kebutuhan pelatihan penyuluh. Oleh karena itu, perlu dilakukan koordinasi/kerjasama dengan lembaga penyuluhan di tingkat propinsi/kabupaten/kota untuk menentukan kebutuhan pelatihan penyuluh dan penyusunan program pelatihannya. Disamping itu, lembaga pelatihan juga perlu dilengkapi dengan personil yang handal dan profesional. Oleh karena itu kemampuan personil lembaga pelatihan masih perlu ditingkatkan sehingga menjadi sumberdaya manusia yang handal dan profesional dengan pendidikan dan pelatihan yang sifatnya substantif.

Penataan program dan peningkatan kemampuan personil lembaga pelatihan perlu dibarengi dengan aspek 
pembiayaan. Karena tanpa adanya biaya yang memadai, sasaran dan target yang dicanangkan akan sulit untuk dicapai. Sumber pembiayaan ini dapat dipenuhi dari berbagai sumber pembiayaan, seperti dari pemerintah (APBN, APBD), bantuan kelembagaan internasional atau negara sahabat (baik sebagai loan ataupun grant) ataupun melalui kerjasama kelembagaan/kalangan usaha swasta dalam mekanisme kerjasama operasional yang saling menguntungkan.

\section{Lembaga Pembuat Kebijakan}

Sub sistem ini bertugas menyusun kebijakan/rencana strategis yang menjamin adanya dan berlangsungnya penyuluhan secara efektif dan berkelanjutan. Sebagai sub sistem kebijakan adalah pemerintah mulai dari pusat, propinsi, hingga kabupaten/kota beserta dewan perwakilan pada setiap level tersebut yang berfungsi sebagai badan legislasi dan pengaturan anggaran.

Sebagaimana telah disebutkan di muka, untuk melaksanakan sistem penyuluhan sebagaimana ditetapkan dalam UU No. 16/2006, dibutuhkan peraturan-peraturan yang dikeluarkan oleh Presiden, Gubernur, hingga Bupati/ Walikota dan DPRD di berbagai level. Dalam hal ini, Sarma (2008) menyatakan bahwa, diperlukan 16 peraturan untuk mengimplementasikan UU No. 16/2006. Disamping itu, menurut penulis, masih diperlukan pengaturan secara khusus mengenai kerjasama/koordinasi yang harus dibangun antara Badan Pelaksana Penyuluhan di setiap daerah dengan lembaga-lembaga yang bertugas dalam sub-sistem yang lain (penelitian dan pengkajian, pendidikan khusus/ kedinasan, dan pelatihan). Hal ini karena selama ini lembaga-lembaga tersebut tidak mempunyai hubungan struktural/formal dan dalam UU No. 16/2006 juga tidak diatur. Undang-undang tersebut pada hakakatnya baru mengatur sub-sistem kebijakan dan sub-sistem penyuluhan, belum menyinggung sub-sistem yang lain-lain sehingga belum terbentuk konsep Sistem Penyuluhan yang utuh dan terintegrasi. Tentunya hal ini menjadi pekerjaan rumah bagi para pemegang otoritas dan hal ini tidak akan menjadi masalah, jika semangat keberpihakan akan dilaksanakannya UU tersebut kuat sehingga peraturan-peraturan tersebut dikerjakan dengan sungguh-sungguh.

Berdasarkan amanah UU No. 16/2006 dan pemikiran seperti di atas serta dalam kerangka otonomi daerah, maka penulis mencoba menggambarkan sistem penyuluhan pertanian, perikanan, dan kehutanan seperti disajikan pada Gambar 1.

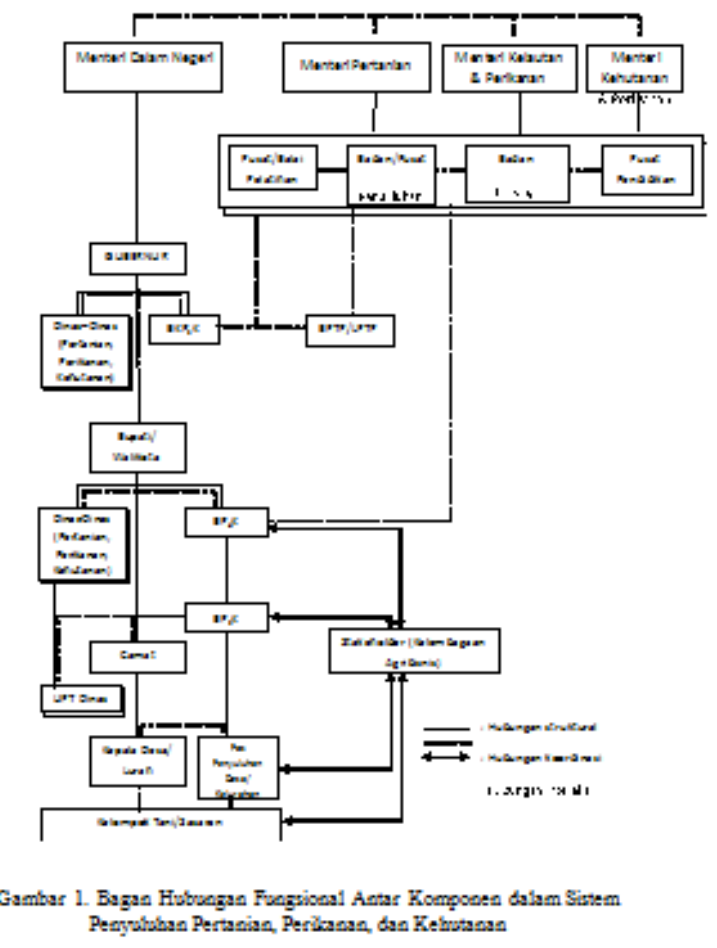

Untuk menunjang sistem penyuluhan yang efektif, maka dipandang perlu dilakukan perbaikan kebijakan yang terkait dengan: rekrutmen sumberdaya manusia penyuluh, pendanaan

kegiatan penyuluhan, pengembangan

$$
\text { Man Rasio Land }=\frac{1.175}{5.200}=0.23
$$

karir penyuluh, dan koordinasi/kerjasama antar subsistem penyuluhan.

\section{Rekrutmen Sumberdaya Manusia Penyuluh}

Berkurangnya jumlah penyuluh pertanian akibat banyaknya penyuluh yang sudah memasuki masa pensiun dan banyak yang beralih tugas ke struktural telah menyebabkan banyak desa maupun kecamatan yang tidak memiliki lagi tenaga penyuluh. Berkaitan dengan hal itu maka diperlukan rekrutmen penyuluh pertanian kembali. Pemerintah telah berencana untuk merekrut kembali penyuluh dalam jumlah yang cukup besar dalam waktu dekat (10.000 - 20.000 penyuluh). Berkaitan dengan itu maka proses rekrutmen perlu dilakukan dengan baik sehingga orang-orang yang direkrut merupakan orangorang yang mempunyai dedikasi tinggi terhadap penyuluhan dan petani. Penyuluh pertanian merupakan pekerjaan yang spesifik, sehingga dalam rekrutmen diperlukan persyaratan yang spesifik (misalnya: pendidikan minimal D3/D4/S1 bidang pertanian dari akademi/universitas berakreditasi baik) dan orang-orang yang direkrut harus merupakan orang-orang yang terpilih. Hal ini sejalan dengan pemikiran Padmanagara (Ekstensia, 2005) yang menyatakan bahwa untuk menjadi penyuluh pertanian tidak hanya cukup dengan telah lulus sebagai pegawai negeri sipil saja. Menjadi penyuluh adalah panggilan jiwa dan sebelum menjadi penyuluh harus ada proses pengenalan lingkup kerja dan bagaimana orang itu menempatkan dirinya di tengah masyarakat petani. Penyuluhan di masa sekarang dan masa depan juga menghadapi tantangan yang makin besar dengan adanya demokratisasi dan globalisasi. Dalam kaitan itu,

330 Sadono, Dwi. Mengembangkan Sistem Penyuluhan Pertanian, Perikanan, dan Kehutanan dalam Rangka Implementasi Undang-Undang Nomor 16 Tahun 2006 
Soedijanto (2003) menyatakan bahwa pekerjaan penyuluh bukan "mengubah cara bertani" tetapi "mengubah petani”.

\section{Pendanaan Kegiatan Penyuluhan}

Setelah dua tahun dikeluarkannya UU No. 16 Tahun 2006 tentang Sistem Penyuluhan Pertanian, Perikanan, dan Kehutanan, sebagian besar kabupaten/kota belum membentuk lembaga baru pelaksana penyuluhan pertanian, perikanan, dan kehutanan. Di Jawa Barat misalnya, setelah dua tahun diundangkannya UU tersebut baru terdapat tujuh kabupaten/kota yang sudah mempunyai kelembagaan penyuluhan yang baru (BP4K). Kelembagaan koordinasi penyuluhan di propinsi (BKP3K) juga belum dibentuk.

Hal ini menggambarkan bahwa masih banyak daerah yang memiliki persepsi beragam hingga yang menganggap kelembagaan penyuluhan pertanian sebagai kelembagaan yang kurang memiliki kontribusi terhadap pengembangan daerahnya. Hal ini terbukti dengan beragamnya kelembagaan penyuluhan pertanian yang ada seperti telah disebutkan pada bab sebelumnya. Oleh karena itu pemerintah perlu mendorong daerah untuk segera mendirikan kelembagaan yang menangani penyuluhan pertanian, perikanan, dan kehutanan.

Dalam hal pembiayaan kegiatan penyuluhan, daerah masih mengandalkan sumber utama dari pemerintah pusat, seperti dari Dana Alokasi Khusus (DAK), Biaya Operasional Penyuluhan (BOP), dan lainnya. Dana yang bersumber dari APBD jika sudah dikeluarkan Perda-nya, umumnya masih dalam jumlah yang sedikit. Oleh karena itu pemerintah pusat masih perlu menyediakan anggaran untuk kegiatan penyuluhan di daerah disamping perlu untuk terus mendorong agar daerah bersedia ikut membiayai kegiatan penyuluhan secara proporsional dan memadai.

\section{Pengembangan Karir Penyuluh}

Mencapai karir yang baik merupakan hal yang dicitacitakan oleh setiap pegawai negeri, demikian pula penyuluh. Untuk itu sistem pengembangan karir penyuluh pertanian perlu mempertimbangkan hal tersebut.

Hasil diskusi dengan penyuluh di Kabupaten Bogor dan Kabupaten Sukabumi, memberikan informasi bahwa peraturan baru (tahun 1999 dan tahun 2006) yang memisahkan jenjang karir penyuluh menjadi penyuluh trampil dan penyuluh ahli membuat penyuluh yang bukan sarjana/diploma 4 menjadi kurang termotivasi terutama bagi yang sudah tidak mempunyai kesempatan untuk melanjutkan ke jenjang S1/D4. Oleh karena itu, penyuluh trampil perlu diberikan kesempatan dapat mencapai jenjang jabatan fungsional paling tidak sampai golongan IV/c seperti pada penjejangan fungsional pada peraturan sebelumnya atau bahkan sampai golongan IV/e seperti pada penyuluh ahli. Kesempatan ini perlu diberikan kepada penyuluh trampil yang mempunyai prestasi yang baik (penyuluh teladan kabupaten/propinsi, mempunyai karya tulis penyuluhan yang baik yang diterbitkan di majalah/jurnal, dan sebagainya). Hal ini seperti guru (SDSMA) yang mempunyai peluang sampai IV/e, dengan syarat untuk mencapai IV/b ke atas disayaratkan menghasilkan karya tulis bidang pendidikan yang diterbitkan di majalah/jurnal.

Kemudian dalam hal insentif berupa tunjangan fungsional, perlu adanya pemberian insentif yang sama antara penyuluh trampil dengan penyuluh ahli sehingga tidak terjadi kecemburuan dan penyuluh trampil yang dalam perjalanan karirnya mencapai gelar S1/D4 tidak perlu berpindah status menjadi penyuluh ahli. Dengan demikian tidak terjadi kerancuan di lapangan, seorang penyuluh ahli tetapi tugas sehari-harinya mengerjakan pekerjaan penyuluh trampil. Perlu terdapat pemisahan bahwa penyuluh trampil bekerja di lapangan dan penyuluh ahli bekerja di level kabupaten/kota, propinsi, pusat, yang berfungsi membina penyuluh trampil dan di BPTP/LPTP

\section{Koordinasi/Kerjasama antar Subsistem Penyuluhan}

Sebagai suatu sistem, untuk dapat memberikan pelayanan penyuluhan yang baik maka setiap sub unsur harus melakukan koordinasi/kerjasama yang efektif dengan sub unsur yang lain. Koordinasi/kerjasama ini tidak hanya secara formal ada strukturnya atau naskah kerjasama, tetapi secara fungsional harus ada hubungan tersebut. Setiap komponen sistem memerlukan masukan (inputs) dan mengeluarkan hasil (outputs). Setiap komponen harus jelas darimana inputs diperlukan dan kemana outputs harus disalurkan. Misalnya lembaga pelaksana penyuluhan, memerlukan inputs materi penyuluhan yang berasal dari lembaga penelitian, pengkajian, dan dari departemen/dinas terkait. Oleh karena itu, antar komponen tersebut harus ada transaksi inputs atau outputs dengan komponen lain, tidak hanya saling memberi informasi. Setiap komponen perlu menyadari bahwa mereka merupakan bagian dari sistem penyuluhan dan prestasi penyuluhan secara keseluruhan merupakan kontribusi dari masing-masing komponen.

\section{Penutup}

Terbitnya UU No. 16 Tahun 2006 menjadi tonggak baru penyelenggaraan penyuluhan pertanian (arti luas) di Indonesia yang selama dua dekade terakhir mengalami stagnasi bahkan kemunduran sejak diberlakukannya otonomi daerah pada dekade terakhir. Penyuluhan sebagai sistem, agar dapat berjalan efektif maka subsistemsubsistemnya perlu dikembangkan/diperbaiki, peraturanperaturan yang diperlukan harus segera dibuat, dan perlu penyamaan persepsi diantara para pihak pada masingmasing subsistem agar terjadi hubungan secara fungsional antar subsistem tersebut.

\section{DAFTAR PUSTAKA}

Abbas, S. (Ed.). 1995. Sembilan Puluh Tahun Penyuluhan Pertanian di Indonesia. Lokakarya Dinamika dan Perspektif Penyuluhan Pertanian pada PJP II Tanggal 4-5 Juli 1995. Bogor.

Asngari, P. S. 2008. Pentingnya Memahami Falsafah Penyuluhan Pembangunan dalam Rangka Pemberdayaan Masyarakat dalam I. Yustina dan A. Sudradjat (Penyunting). 2008. Pemberdayaan Manusia Pembangunan yang Bermartabat. 
Didedikasikan kepada Prof. Dr. Pang S. Asngari. Sydex Plus. Medan.

Axinn, G.H. 1988. Guide on Alternative Extension Approaches. FAO of The United Nations. Rome.

BPLPP. 1978. Tujuh Puluh Tahun Penyuluhan Pertanian di Indonesia 1908-1978. BPLPP Departemen Pertanian. Jakarta.

Departemen Kehutanan. 2006. UU No. 16 Tahun 2006 tentang Sistem Penyuluhan Pertanian, Perikanan, dan Kehutanan. Pusat Bina Penyuluhan Kehutanan, Departemen Kehutanan. Jakarta.

Ekstensia. 1996. "Revitalisasi" : Menyibak Kemelut Penyuluhan Pertanian dengan Kearifan. Ekstensia, Vol. 03 Tahun 1996. Badan Pengembangan Sumberdaya Manusia Pertanian, Departemen Pertanian. Jakarta.

Ekstensia. 2005. Revitalisasi Penyuluhan Pertanian: Merajut Kembali Daya Hidup Penyuluhan Pertanian. Ekstensia, Vol. 01 Tahun 2005. Badan Pengembangan Sumberdaya Manusia Pertanian, Departemen Pertanian. Jakarta.

Girsang, W. 1989. Peranan Organisasi Kelembagaan Balai Penyuluhan Pertanian dalam Supra Insus. Skripsi Jurusan Sosek Faperta IPB. Bogor.

Hubeis, A.V.S. 1993. Strategi Penyuluhan Pertanian Sebagai Salah Satu Upaya Menswadayakan Petani Nelayan. Makalah Seminar Sehari Ulang Tahun Perhiptani ke-5, tanggal 1 Desember 1993. Jakarta.

Iskandar, G. 1969. Penyuluhan Pertanian dalam Waktu yang Sudah Silam dan Waktu yang Kita Hadapi Sekarang. Makalah pada Workshop Sosiologi Pedesaan dan Penyuluhan IPB. Bogor.

Loomis, C. P. 1960. Social Systems: Essays on Their Persistence and Change. The van Nostrand Company, Inc. London.

Mugniesjah, S.S.M dan D. Sadono. 1998. Balai Informasi dan Penyuluhan Pertanian Kabupaten Karawang. Jurusan Sosial Ekonomi Pertanian Faperta IPB. Bogor.

Pasandaran, E. dan O. K. Adnyana. 1995. Peranan Balai Pengkajian Teknologi Pertanian (BPTP) dalam Meningkatkan Keterkaitan antara Peneliti dan Penyuluh. Makalah pada Lokakarya Dinamika dan Perspektif Penyuluhan Pertanian pada PJP II. Bogor, 5-6 Juli 1995.

Sarma, M. 2008. Pengorganisasian Penyuluhan Menurut Undang-Undang No. 16/2006: Catatan Kritis dalam Pengimplementasiannya dalam I. Yustina dan A. Sudradjat (Penyunting). 2008. Pemberdayaan Manusia Pembangunan yang Bermartabat. Didedikasikan kepada Prof. Dr. Pang S. Asngari. Sydex Plus. Medan

Slamet, M. 2001. Paradigma Baru Penyuluhan Pertanian di Era Otonomi Daerah dalam I. Yustina dan A. Sudradjat (eds). Membentuk Pola Perilaku
Manusia Pembangunan: Didedikasikan kepada Prof. Dr. H.R. Margono Slamet. IPB Press. Bogor.

Slamet, M. 2008. Menuju Pembangunan Berkelanjutan Melalui Implementasi UU No. 16/2006 tentang Sistem Penyuluhan Pertanian, Perikanan, dan Kehutanan dalam I. Yustina dan A. Sudradjat (Penyunting). 2008. Pemberdayaan Manusia Pembangunan yang Bermartabat. Didedikasikan kepada Prof. Dr. Pang S. Asngari. Sydex Plus. Medan.

Soedijanto. 2003. Penyuluhan Sebagai Pilar Akselerasi Pembangunan Pertanian di Indonesia pada Masa Mendatang dalam I. Yustina dan A. Sudradjat (eds). Membentuk Pola Perilaku Manusia Pembangunan: Didedikasikan kepada Prof. Dr. H.R. Margono Slamet. IPB Press. Bogor.

Soewardjo. 1953. Balai Pendidikan Masyarakat Desa. Djawatan Pertanian Rakjat, Departemen Pertanian. Jakarta.

Tim Faperta IPB. 1992. Tahun 1963 Perguruan Tinggi Menjawab Tantangan Masalah Pangan - Fakultas Pertanian IPB. Bogor.

Tjitropranoto, P. 2003. Penyuluhan Pertanian: Masa Kini dan Masa Depan dalam I. Yustina dan A. Sudradjat (eds). Membentuk Pola Perilaku Manusia Pembangunan: Didedikasikan kepada Prof. Dr. H.R. Margono Slamet. IPB Press. Bogor.

Pramita, Y. 2007. Analisis kebutuhan Pelatihan bagi Penyuluh Pertanian pada Dinas Pertanian dan Kehutanan Kabupaten Bogor (Skripsi) Fakultas Pertanian IPB, Bogor

332 Sadono, Dwi. Mengembangkan Sistem Penyuluhan Pertanian, Perikanan, dan Kehutanan dalam Rangka Implementasi Undang-Undang Nomor 16 Tahun 2006 